\title{
EFEKTIVITAS PELAYANAN IZIN MENDIRIKAN BANGUNAN PADA DINAS PENANAMAN MODAL DAN PELAYANAN TERPADU SATU PINTU KOTA AMBON
}

\section{Montgomery Warbal}

Sekolah Tinggi Ilmu Administrasi (STIA) Trinitas Ambon, Indonesia

Email: montywarbal@gmail.com

\begin{abstract}
Abstrak
Penelitian ini memiliki tujuan untuk menjelaskan serta mendiskripsikan foktorfactor yang menyebabkan keterlambatan perizinan pada Dinas Penanaman Modal dan Pelayanan Terpadu Satu Pintu Di Kota Ambon,untuk mengetahui kebijakan -kebijakan yang dilaksanakan dalam peningkatan pelayanan izin mendirikan bangunan pada Dinas Penanaman Modal dan Pelayanan Terpadu Satu Pintu Di Kota. Metode penelitian yang digunakan dalam penelitian ini adalah pendekatan kuantitatif dimana dalam penelitian ini yang dilakukan bersifat diskriptif yaitu untuk mengetahui atau menggambarkan kenyataan dari kejadian yang diteliti.analisis data dilakukan secara terus menerus dimulai dengan menelaah seluruh data yang tersedia dari berbagai sumber, yaitu wawancara, pengamatan yang sudah dituliskan dalam catatan lapangan, dokumen dan sebagainya sampai dengan penarikan kesimpulan. Hasil Penelitian menunjukan bahwa dari 6 indikator yang diajukan,namun ada 2 faktor yang menghambat yakni :1 ). Faktor aturan belum sepenuhnya dijalankan oleh para pegawai diakibatkan karena kurangnya pengawasan daei pimpinan dan factor kesadaran belum sepenuhnya dijalankan karena kurangnya disiplin pegawai dalam melaksanakan pelayanan surat IMB, sehingga terjadi keterlambatan dalam penerbitan IMB. Sedangkan kebijakan yang diambil adalah : 1). Mengadakan rapat rutin mengenai penerbitan IMB yang mengalami keterlambatan, 2). Melakukan pengawasan dan pembinaan, 3). Mengikuti pendidikan dan pelatihan- pelatihan bimbingan teknis pada Dinas Penanaman Modal dan Pelayanan Terpadu Satu Pintu Di Kota Ambon.
\end{abstract}

Kata Kunci: efektivitas pelayanan; pemberian izin mendidirkan bangunan

\section{Abstract}

This study aims to explain and describe the factors that cause delays in licensing at the One Stop Integrated Service and Investment Service in Ambon City, to find out the policies implemented in improving building permit services at the Investment Office and One Stop Integrated Services. In the city. The research method used in this study is a quantitative approach which in this research is descriptive, namely to find out or describe the reality of the events being studied. Data analysis is carried out continuously starting by examining all available

How to cite:
Published by:
Warbal. Montgomery (2021) Efektivitas Pelayanan Izin Mendirikan Bangunan pada Dinas Penanaman Modal dan Pelayanan Terpadu Satu Pintu Kota Ambon. Syntax Literate: Jurnal Ilmiah Indonesia, 6(2) $2548-1398$

Ridwan Institute 
data from various sources, namely interviews, observations which has been written in field notes, documents and so on until the conclusion is drawn. The results showed that of the 6 indicators proposed, there were 2 inhibiting factors, namely: 1). The regulatory factor has not been fully implemented by the employees due to the lack of supervision from the leadership and the awareness factor has not been fully implemented due to the lack of employee discipline in carrying out the IMB letter service, resulting in delays in the issuance of the $I M B$. While the policies taken are: 1). Hold regular meetings regarding delayed issuance of IMBs, 2). Carry out supervision and coaching, 3). Participate in education and technical guidance training at the Office of Investment and One Stop Integrated Services in Ambon City.

Keywords: service effectiveness; granting of building permits

Received: 2021-10-20; Accepted: 2021-11-05; Published: 2021-11-20

\section{Pendahuluan}

Pada dasarnya penyelenggaraan pemerintahan mengemban tiga fungsi hakiki, yaitu pelayanan, pemberdayaan dan pembangunan. Jadi selain melaksanakan pembangunan, pemerintah juga memberikan pelayanan kepada masyarakat atau lebih dikenal dengan pelayanan publik.

Pelayanan pada dasarnya menjadi bagian penting bagi kehidupan manusia. Dalam hal ini, pelayanan kepada masyarakat memiliki tujuan utama yang telah menjadi kewajiban dalam penyelenggaraan pemerintahan dengan memberikan pelayanan yang terbaik kepada masyarakat. Selain itu, pemerintah juga mempunyai peranan penting untuk menyediakan layanan publik yang prima bagi masyarakat mulai dari pelayanan dalam bentuk pengaturan, kesehatan, dan pendidikan.

Masyarakat Indonesia sendiri pada zaman sekarang semakin kritis dalam menginginkan pelayanan yang maksimal dari pemerintah. Dalam kehidupan global yang disertai perubahan zaman dan semakin modernnya kehidupan manusia, teknologi dan yang lainnya ini membawa perubahan dan dampak yang kompleks.

Pada umumnya masyarakat selalu menuntut pelayanan publik yang baik, cepat dan berkualitas dari pemerintah. walaupun tuntutan tersebut sering dilaporkan masyarakat kepada pemerintah, tetapi tetap saja pelayanan masih belum maksimal. Untuk memperoleh pelayanan yang sederhana saja, masyarakat sering dihadapkan dengan beberapa kesulitan, seperti halnya di kantor pemerintah daerah, sering kali ditentukan beberapa masalah birokrasi, misalnya dalam hal perizinan yang butuh waktu dan proses yang lama. Hal ini menunjukkan bahwa pelayanan terhadap masyarakat belum terlaksana dengan baik dan cepat. Padahal pelayanan yang baik dan cepat adalah tujuan utama yang tidak dapat dihindari oleh para pemangku kewajiban penyelenggara pelayanan masyarakat (Yudhaningsih, 2011).

Dalam rangka mewujudkan pelayanan prima kepada masyarakat, pemerintah telah mengeluarkan Keputusan Menteri Pendayagunaan Aparatur Negara Nomor 63 Tahun 2003 tentang Pedoman Umum Penyelenggaraan Pelayanan Publik yang berisi kriteria- 
kriteria pelayanan prima yaitu kesederhanaan, kejelasan dan kepastian pelayanan, keamanan, keterbukaan, efesiensi, ekonomis, keadilan yang merata dan ketetapan waktu.

Dalam organisasi pemerintahan, pelayanan kepada masyarakat adalah tujuan utama yang tidak mungkin dapat dihindari karena sudah merupakan kewajiban menyelenggarakan pelayanan dengan menciptakan pelayanan yang terbaik kepada masyarakat, maka sepatutnya pemerintah mencari solusi terbaik terhadap masalahmasalah yang sering dihadapi, termasuk kendala intern yaitu kendala yang bersumber dari dalam instansi itu sendiri maupun kendala exstern yakni kendala yang datangnya dari masyarakat pengguna jasa dalam kaitannya dengan pelayanan umum yang ditanganinya, selain itu pula pegawai harus senantiasa memberikan pelayanan yang sebaik-baiknya kepada masyarakat secara keseluruhan.

Dengan adanya kualitas pelayanan yang baik maka dapat menimbulkan rasa puas dan sikap positif dari masyarakat. Hal ini dikarenakan kepuasan merupakan perasaan senang atau kekecewaan seseorang yang berasal dari perbandingan antara kesannya terhadap kinerja seseorang dan harapannya.

Masyarakat akan sangat puas apabila dirinya mendapat pelayanan dengan baik, dan tentunya hal tersebut akan membawa kesan positif dalam diri setiap masyarakat khususnya terhadap kinerja aparatur pemerintah. Tingkat kepuasan masyarakat merupakan suatu indikator yang penting bagi keberhasilan pelayanan publik dimana semakin besar manfaat yang dirasakan publik, semakin bagus pula kualitas layanan yang dilaksanakan oleh aparat, sebaliknya tingkat kepuasan yang rendah mengindikasikan buruknya sistem pelayanan aparat publik.

Namun pada kenyataannya, beberapa permasalahan pelayanan publik masih banyak ditemukan di Indonesia, diantaranya yaitu sering terjadinya penyalahgunaan kekuasaan yang dilakukan oleh pihak pemberi pelayanan yang seharusnya menciptakan kesejahteraan dan memberikan pelayanan yang prima kepada masyarakat. Bahkan sampai sekarang masih banyak masyarakat yang mengeluhkan pelayanan yang diberikan oleh pemerintah, seperti lamanya proses pelayanan berbelit-belitnya aturan yang dibuat pemerintah, serta adanya pungutan liar yang seharusnya tidak dikenakan dalam suatu pelayanan. Hasil penelitian dari (Hibali, 2012) ada beberapa kejadian menunjukkan bahwa dalam mengoptimalkan fungsi pelayanan masyarakat, pemerintah. masih kurang mampu dalam melayani masyarakat. Selain itu, masih banyak keluhan dan kritik dari masyarakat tentang pelayanan.

Mengingat pelayanan publik di Indonesia yang masih jauh dari harapan masyarakat dan menjadi salah satu hal yang masih menjadi sorotan, maka pelayanan publik menjadi hal yang perlu diperhatikan dan diselesaikan secara komprehensif. Selain itu, pelayanan publik juga menjadi ujung tombak interaksi antara masyarakat dan pemerintah. Oleh karena itu, dengan adanya tuntutan-tuntutan dari masyarakat untuk mendapatkan pelayanan yang prima, pemerintah harus bisa mengupayakan pelayanan yang baik dan maksimal. Pelayanan publik yang harus diwujudkan dalam setiap 
penyelenggaraan pelayanan publik baik dalam tingkatan pemerintah pusat, pemerintah provinsi, pemerintah kabupaten dan kota.

Kemudian dalam proses implementasi program kerja yang ditetapkan, orientasi dan proyeksi dibutuhkan oleh sebuah organisasi untuk mewujudkan sebuah organisasi yang efektif, oleh karena itu konsep efektivitas dapat digunakan untuk mengevaluasi jalannya suatu organisasi. Efektivitas adalah suatu ukuran yang menyatakan seberapa jauh target (kuantitas, kualitas dan waktu) telah tercapai, Suatu kegiatan dikatakan efisien apabila dikerjakan dengan benar dan sesuai dengan prosedur, sedangkan efektif apabila kegiatan tersebut dilaksanakan dengan benar dan dapat memberikan hasil yang bermanfaat (Siagian, 2006).

Banyaknya jenis pelayanan publik menyebabkan perlu dilakukan batasan kajian pada jenis pelayanan tertentu. Salah satu jenis pelayanan publik yang mendasar adalah pelayanan di sektor administrasi perizinan. Pelayanan dalam sektor administrasi perizinan merupakan jenis pelayanan yang cukup banyak permintaannya seperti Izin Usaha Angkutan, Izin Usaha Perikanan, Izin Usaha Perkebunan, Izin Usaha Perindustrian, lebih dikhususkan lagi tentang Izin Mendirikan Bangunan (IMB).

Saat ini ada banyak hal yang berhubungan dengan masalah pelayanan diantaranya yaitu pelayanan Izin Mendirikan Bangunan (IMB). Izin Mendirikan Bangunan (IMB) merupakan Keputusan Pemerintah Tata Usaha Negara (KTUN) yang wajib dimiliki oleh setiap bangunan gedung. Izin Mendirikan Bangunan (IMB) berfungsi sebagai sarana pengendali untuk menjamin bahwa bangunan yang akan dibangun dapat menjamin keselamatan orang-orang yang akan tinggal di dalam gedung tersebut serta orang-orang di sekitarnya.

Izin Mendirikan Bangunan sebagai sarana perizinan dalam mendirikan bangunan dapat digunakan sebagai standar penyesuaian bangunan yang dapat melindungi keamanan masyarakat serta lingkungan sekitarnya. Selain itu Izin Mendirikan Bangunan juga dapat digunakan sebagai jaminan hukum yang sah kepada masyarakat terhadap kepemilikan gedung Izin Mendirikan Bangunan tentunya sangat diperlukan khususnya di Kota Ambon sebagai daerah rawan bencana alam.

Tentunya butuh suatu proses untuk mendapatkan Izin Mendirikan Bangunan. Oleh karena itu efektivitas pelayanan dalam pembuatan Izin Mendirikan Bangunan (IMB) juga sangat diperlukan untuk kelancaran dan ketepatan proses pembuatannya. Selain itu, mengingat fenomena yang terjadi pada masyarakat, seperti kerusuhan, unjuk rasa dan demonstrasi yang berlebihan akibat rasa kecewa masyarakat terhadap pelayanan pemerintah yang tidak sesuai dengan keinginan masyarakat menunjukkan bahwa pelayanan pemerintah terhadap masyarakat masih belum efektif.

Berkaitan dengan pemberian pelayanan perizinan IMB, salah satu lembaga yang melayani Izin Mendirikan Bangunan adalah kantor perizinan. Sebagai organisasi pemerintahan yang berkewajiban untuk melayani masyarakat dengan baik sudah seharusnya pemerintah memberikan pelayanan yang baik, murah, sederhana, akuntabilitas dan transparan, serta bisa dipertanggungjawabkan kepada publik, tetapi masih ditemukan beberapa permasalahan dalam hal permohonan Izin Mendirikan 
Bangunan (IMB) seperti halnya yang terjadi di Dinas Penanaman Modal dan Pelayanan Terpadu Satu Pintu Kota Ambon.

Faktor-faktor yang menyebabkan masyarakat masih merasa belum merasa puas terhadap pelayanan yang diberikan, sehingga berdampak pada masih ada sebagian masyarakat yang tidak memiliki izin pada saat mendirikan bangunan karena : biaya pengurusan izin sangat memberatkan bagi usaha kecil, besarnya biaya perizinan seringkali tidak transparan disebabkan karena pemohon tidak mengetahui besar biaya resmi untuk pengurusan izin, dan karena adanya pungutan liar. Masalah ini belum teratasi oleh pihak pemerintah Kota Ambon disebabkan dalam menjalankan pelayanan kurang maksimal, hal ini ditandai dengan indikasi-indikasi sebagai berikut :1. Faktor kesadaran, 2. Faktor aturan 3. Faktor organisasi : 4. Faktor kemampuan 5. Sarana dan prasarana kurang menunjang

Kurang optimalnya pelayanan kepada masyarakat pengguna layanan dari Dinas Penanaman Modal dan Pelayanan Terpadu Satu Pintu Kota Ambon merupakan fenomena yang banyak terjadi pada sektor pemerintahan, padahal seharusnya fungsi pemerintah memberikan pelayanan kepada masyarakat tanpa pandang bulu dan sesuai dengan keputusan MENPAN Nomor 63 tahun 2003 dan hendaknya bekerja lebih ekstra agar pelayanan publik lebih efektif. Oleh karena itu, peningkatan efektivitas pelayanan perizinan sangat perlu dilakukan agar masyarakat merasa puas dengan pelayanan yang dilakukan oleh lembaga terkait dan keluhan-keluhan tentang pelayanan menjadi berkurang dan bahkan sudah tidak ada lagi.

Beberapa hal yang berkaitan dengan pelayanan publik, khususnya pelayanan permohonan Izin Mendirikan Bangunan (IMB) menjadi hal yang sangat perlu untuk diperhatikan dan mengingat beberapa permasalahan yang telah dijelaskan di atas. Oleh karena itu, untuk mengetahui tingkat efektivitas pelayanan Izin Mendirikan Bangunan di Dinas Penanaman Modal Dan Pelayanan Terpadu Satu Pintu Kota Ambon.

\section{Metode Penelitian}

Metode yang dilakukan untuk mengolah dan menganalisis penelitian ini adalah metode penelitian deskriptif, yakni sebagai metode penelitian untuk membuat gambaran mengenai situasi atau kejadian, sehingga metode ini berkehendak mengadakan akumulasi data dasar belaka (Nasir, 2018 : 85)

\section{Populasi Penelitian}

Penelitian ini berhubungan dengan efektivitas pelayanan ijin mendirikan bangunan, maka yang akan penulis jadikan populasi adalah seluruh pemohon dalam perijinan mendirikan bangunan di Dinas Penanaman Modal dan Pelayanan Terpadu Satu Pintu Kota Ambon terhitung 3 bulan terakhir dari bulan Februari sampai dengan bulan April 2020 yang berjumlah 71 pemohon.

\section{Teknik Penarikan Sampel}

Teknik yang digunakan dalam penelitian ini adalah teknik non probability sampling yakni teknik pengambilan sampel yang tidak memberi peluang/kesempatan sama bagi setiap unsur atau anggota populasi untuk dipilih menjadi sampel (Sugiyono, 
2012), karena jumlah pegawai sedikit dan dapai dijangkau, sehingga tidak diadakan penarikan sampel, sehingga digunakan sampel jenuh yakni teknik penentuan sampel bila semua anggota populasi digunakan sebagai sampel (Sugiyono, 2012).

Disamping itu penulis menggunakan Sampling aksidental adalah teknik penentuan sampel berdasarkan kebetulan, yaitu siapa saja yang secara kebetulan bertemu dengan peneliti dapat digunakan sebagai sampel, bila dipandang orang yang kebetulan ditemui itu cocok sebagai sumber data (Sugiyono, 2017).

\section{Hasil dan Pembahasan}

\section{Faktor-Faktor yang Mempengaruhi Keterlambatan Pelayanan Izin Mendirikan Bangunan Pada Dinas Penanaman Modal dan Pelayanan Terpadu Satu Pintu Kota Ambon}

1) Faktor Kesadaran

Faktor kesadaran petugas yang berkecimpung dalam pelayanan, kesadaran disini berfungsi sebagai acuan dasar yang melandasi pada perbuatan atau tindakan berikutnya. Sub indikator faktor kesadaran meliputi sikap keramahan pegawai dalam pelayanan kepada masyarakat, tanggapan pegawai terhadap keluhan, kedisplinan waktu, penyelesaian masalah yang berlarut-larut, sikap dan tingkah laku pegawai dalam pelaksanaan tugas. Untuk mengetahui jawaban responden dari pertanyaan diatas dapat dilihat pada tabel berikut ini :

\section{Tabel 1}

Rekapitulasi Tanggapan Responden Indikator Faktor Kesadaran

\begin{tabular}{|c|c|c|c|c|c|c|c|c|c|c|c|}
\hline \multirow{3}{*}{$\begin{array}{l}\text { Indikator } \\
\text { Pelayanan } \\
\end{array}$} & \multicolumn{10}{|c|}{ Persentase \% } & \multirow{3}{*}{ TOTAL } \\
\hline & \multicolumn{2}{|c|}{ SS } & \multicolumn{2}{|c|}{$\mathbf{S}$} & \multicolumn{2}{|c|}{ CS } & \multicolumn{2}{|c|}{ KS } & \multicolumn{2}{|c|}{ TS } & \\
\hline & $\mathbf{F}$ & $\%$ & $\mathbf{F}$ & $\%$ & $\mathbf{F}$ & $\%$ & $\mathbf{F}$ & $\%$ & $\mathbf{F}$ & $\%$ & \\
\hline $\begin{array}{l}\text { Sikap keramahan } \\
\text { pegawai dalam } \\
\text { pelayanan } \\
\text { kepada } \\
\text { masyarakat }\end{array}$ & 19 & 27 & 30 & 42 & 22 & 31 & - & - & - & - & 71 \\
\hline $\begin{array}{l}\text { Tanggapan } \\
\text { pegawai terhadap } \\
\text { keluhan } \\
\text { masyarakat }\end{array}$ & 20 & 28 & 20 & 28 & 31 & 44 & - & - & - & - & 71 \\
\hline $\begin{array}{l}\text { Kedisiplinan } \\
\text { waktu }\end{array}$ & 18 & 25 & 13 & 18 & 40 & 56 & - & - & - & - & 71 \\
\hline $\begin{array}{l}\text { Penyelesaian } \\
\text { masalah yang } \\
\text { berlarut-larut }\end{array}$ & 19 & 27 & 22 & 31 & 30 & 42 & - & - & - & - & 71 \\
\hline $\begin{array}{lr}\text { Sikap } & \text { dan } \\
\text { tingkah } & \text { laku } \\
\text { pegawai } & \text { dalam } \\
\text { pelaksanaan } & \end{array}$ & 45 & 63 & 20 & 28 & 6 & 9 & - & - & - & - & 71 \\
\hline
\end{tabular}


Efektivitas Pelayanan Izin Mendirikan Bangunan pada Dinas Penanaman Modal dan Pelayanan Terpadu Satu Pintu Kota Ambon

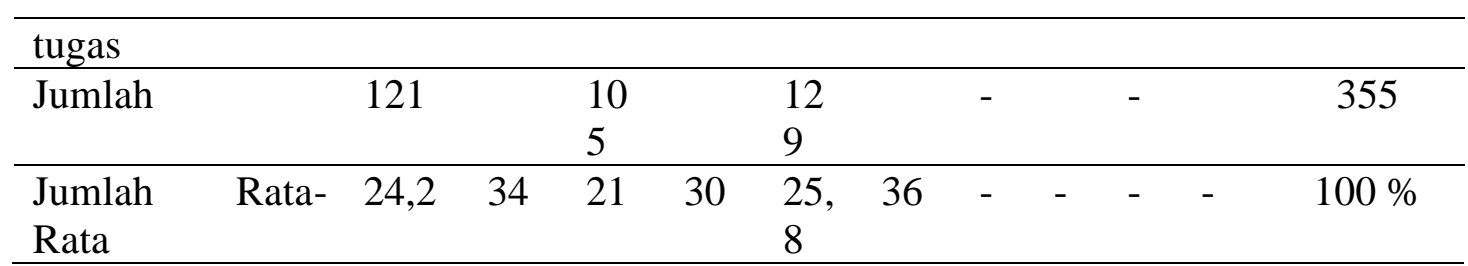

Sumber : Hasil Olahan Data Agustus 2020

Rekapitulasi diatas, memperlihatkan bahwa responden yang menyatakan sangat setuju terdapat 24,2 responden atau sekitar 34\%, untuk responden yang menyatakan setuju terdapat 21 responden atau sekitar $30 \%$, untuk responden yang menyatakan setuju terdapat 25,8 responden atau sekitar $36 \%$ mengatakan cukup setuju.

Hal ini menunjukkan bahwa faktor kesadaran pegawai tidak menjadi kendala atau penghambat untuk mendapatkan pelayanan guna mewujudkan pelayanan yang optimal kepada masyarakat.

Namun berdasarkan wawancara penulis dengan (Juanito, masyarakat yang pernah mengurus IMB), sebagai berikut:

"Bagaimana menurut bapak mengenai sikap pegawai dalam memberikan pelayanan di Dinas Penanaman Modal dan Pelayanan Terpadu Satu Pintu Kota Ambon". ?

"Saya merasa pelayanan dalam mengurus IMB di Dinas Penanaman Modal dan Pelayanan Terpadu Satu Pintu Kota Ambon kurang baik karena ada sebagian pegawai yang kurang peduli terhadap keluhan. Kalau bagus pelayanannya pasti saya tidak mengeluh. Sewaktu mengurus pegawai mengatakan IMB diselesaikan paling lama 14 hari kerja, setelah terhitung lebih dari 14 hari kerja, ketika saya didatangi ternyata belum siap juga, malahan mereka mengatakan, nanti kalau sudah siap IMB-nya kami hubungi bapak.” (Wawancara, 25 Juli 2020)

2) Faktor Aturan

Faktor aturan yang menjadi landasan kerja pelayanan yaitu merupakan perangkat penting dalam segala tindakan dan perbuatan orang. Faktor ini menyangkut segala ketentuan baik yang tertulis maupun yang tidak tertulis yang berlaku didalam organisasi. Sub indikator faktor aturan meliputi kedisiplinan dalam pelaksanaan kerja, ketepatan waktu masuk kantor, kehadiran apel pagi, prosedur pelayanan, dan pemahaman pegawai terhadap tupoksi. Untuk mengetahui jawaban responden dari pertanyaan diatas dapat dilihat pada tabel berikut ini :

Tabel 2

Rekapitulasi Tanggapan Responden Indikator Faktor Aturan

\begin{tabular}{|c|c|c|c|c|c|c|c|c|c|c|c|}
\hline \multirow{3}{*}{$\begin{array}{l}\text { Indikator } \\
\text { Pelayanan }\end{array}$} & \multicolumn{10}{|c|}{ Persentase \% } & \multirow{3}{*}{ TOTAL } \\
\hline & \multicolumn{2}{|c|}{ SS } & \multicolumn{2}{|c|}{$\mathbf{S}$} & \multicolumn{2}{|c|}{ CS } & \multicolumn{2}{|c|}{ KS } & \multicolumn{2}{|c|}{ TS } & \\
\hline & $\mathbf{F}$ & $\%$ & $\mathbf{F}$ & $\%$ & $\mathbf{F}$ & $\%$ & $\mathbf{F}$ & $\%$ & $\mathbf{F}$ & $\%$ & \\
\hline $\begin{array}{l}\text { Kedisiplinan } \\
\text { dalam } \\
\text { pelaksanaan }\end{array}$ & 19 & 27 & 15 & 21 & 28 & 39 & 9 & 13 & - & - & 71 \\
\hline
\end{tabular}




\begin{tabular}{llllllllllll}
\hline kerja & \multicolumn{1}{l}{ Ketepatan } \\
$\begin{array}{l}\text { waktu masuk } \\
\text { kantor }\end{array}$ & 19 & 27 & 19 & 27 & 30 & 42 & 3 & 4 & - & - & 71 \\
\hline $\begin{array}{l}\text { Kehadiran } \\
\text { apel pagi }\end{array}$ & 17 & 24 & 13 & 18 & 38 & 54 & 3 & 4 & - & - & 71 \\
\hline $\begin{array}{l}\text { Prosedur } \\
\text { pelayanan }\end{array}$ & 37 & 52 & 16 & 23 & 18 & 25 & - & - & - & - & 71 \\
\hline $\begin{array}{l}\text { Pemahaman } \\
\text { pegawai } \\
\text { terhadap } \\
\text { tupoksi tugas }\end{array}$ & 17 & 24 & 18 & 25 & 34 & 48 & - & - & 2 & 3 & 71 \\
\hline Jumlah & 109 & & 81 & & 148 & & 15 & & 2 & & 355 \\
\hline $\begin{array}{l}\text { Jumlah Rata- } \\
\text { Rata }\end{array}$ & 21, & 31 & 16 & 23 & 29, & 42 & 3 & 4 & 0,4 & 0,1 & $100 \%$ \\
\hline
\end{tabular}

Sumber : Hasil Olahan Data Agustus 2020

Rekapitulasi diatas, memperlihatkan bahwa responden yang menyatakansangat setuju terdapat 21,8 responden atau sekitar $31 \%$, untuk responden yang menyatakan sangat setuju terdapat 16,2 responden atau sekitar 23\%, untuk responden yang menyatakan setuju terdapat 29,6 responden atau $42 \%$, untuk yang menyatakan cukup setuju terdapat responden atau $4 \%$ yang menyatakan kurang setuju dan yang menyatakan tidak setuju sekitar 0,4 atau $0,1 \%$.

Hal ini menunjukkan bahwa aturan yang ada di Dinas Penanaman Modal dan Pelayanan Terpadu Satu Pintu Kota Ambon belum sepenuhnya dijalankan oleh para pegawai diakibatkan kurangnya pengawasan pimpinan.

Berdasarkan hasil wawancara kepadapenulis dengan informan (Juanito, masyarakat yang pernah mengurus IMB), sebagai berikut : "Bagaimana menurut bapak mengenai keberadaan pegawai pada saat jam kerja?".

"Saya mendatangi kantor Dinas Penanaman Modal dan Pelayanan Terpadu Satu

Pintu Kota Ambon pada saat jam kerja jam 08.30, ketika saya sampai untuk mengambil IMB, petugas bagian informasi dengan santainya mengatakan “pegawainya sedang sarapan pak. Tunggu saja dulu”. Kalau pegawainya tidak berada ditempat karena sakit atau dinas diluar tidak menjadi masalah, tetapi pegawai tidak ada ditempat karen asarapan.”(Wawancara 25 Juli 2020)

3) Faktor Organisasi

Faktor organisasi yang meliputi pengaturan struktur organisasi yang menggambarkan hirarki pertanggungjawaban, pembagian kerja yang berdasarkan keahlian dan fungsinya. Masing-masing bagian sesuai dengan tugas yang telah ditetapkan serta usaha mengembangkan organisasi. Sub indikator faktor organisasi meliputi kerja sama antar pegawai, pembagian kerja berdasarkan keahlian dan fungsinya, tanggung jawab terhadap bidang tugasnya, team work pendukung dalam pelakasanaan tugas, penggunaan waktu dalam pelaksanaan tugas secara optimal. Untuk 
mengetahui jawaban responden dari pertanyaan diatas dapat dilihat pada tabel berikut ini:

Tabel 3

Rekapitulasi Tanggapan Responden Indikator Faktor Organisasi

\begin{tabular}{|c|c|c|c|c|c|c|c|c|c|c|c|}
\hline \multirow{3}{*}{$\begin{array}{l}\text { Indikator } \\
\text { Pelayanan }\end{array}$} & & & \multicolumn{8}{|c|}{ Persentase \% } & \multirow{3}{*}{ TOTAL } \\
\hline & \multicolumn{2}{|c|}{ SS } & \multicolumn{2}{|c|}{$\mathbf{S}$} & \multicolumn{2}{|c|}{ CS } & \multicolumn{2}{|c|}{ KS } & \multicolumn{2}{|c|}{ TS } & \\
\hline & $\mathbf{F}$ & $\%$ & $\mathbf{F}$ & $\%$ & $\mathbf{F}$ & $\%$ & $\mathbf{F}$ & $\%$ & $\mathbf{F}$ & $\%$ & \\
\hline $\begin{array}{l}\text { Kerja sama } \\
\text { antar } \\
\text { pegawai }\end{array}$ & 19 & 27 & 35 & 49 & 17 & 24 & - & - & - & - & 71 \\
\hline $\begin{array}{l}\text { Pembagian } \\
\text { kerja } \\
\text { berdasarkan } \\
\text { keahlian dan } \\
\text { fungsinya }\end{array}$ & 15 & 21 & 19 & 27 & 31 & 44 & 6 & 8 & - & - & 71 \\
\hline $\begin{array}{l}\text { Tanggung } \\
\text { jawab } \\
\text { terhadap } \\
\text { bidang tugas }\end{array}$ & 25 & 35 & 33 & 46 & 13 & 18 & - & - & - & - & 71 \\
\hline $\begin{array}{l}\text { Team work } \\
\text { pendukung } \\
\text { dalam } \\
\text { pelaksanaan } \\
\text { tugas }\end{array}$ & 19 & 27 & 14 & 20 & 24 & 34 & 9 & 13 & 5 & 7 & 71 \\
\hline $\begin{array}{l}\text { Penggunaan } \\
\text { waktu dalam } \\
\text { pelaksanaan } \\
\text { tugas secara } \\
\text { optimal }\end{array}$ & 27 & 38 & 32 & 45 & 12 & 17 & - & - & - & - & 71 \\
\hline Jumlah & $\begin{array}{l}10 \\
5 \\
\end{array}$ & & $\begin{array}{l}13 \\
3 \\
\end{array}$ & & 97 & & 15 & & 5 & & 355 \\
\hline $\begin{array}{l}\text { Jumlah Rata- } \\
\text { Rata }\end{array}$ & 21 & 30 & 27 & 37,4 & 19 & 27 & 3 & 4,2 & 1 & 1,4 & $100 \%$ \\
\hline
\end{tabular}

Sumber : Hasil Olahan Data Agustus 2020

Rekapitulasi diatas, memperlihatkan bahwa responden yang menyatakan sangat setuju terdapat 21 responden atau sekitar $30 \%$, untuk responden yang menyatakan setuju terdapat 27 responden atau sekitar $37,4 \%$, untuk responden yang menyatakan cukup setuju terdapat 19 responden atau $27 \%$, untuk responden yang menyatakan kurang setuju terdapat 3 responden atau 4,2 \%, dan untuk responden yang menyatakan tidak setuju terdapat 1 terdapat 1,4 .

Berdasarkan hasil observasi, sikap dan integritas pegawai untuk melayani masyarakat cukup baik namun setiap pegawai memiliki kewenangan dimasing-masing bagian yang telah ditempatkan sebelumnya. Dalam pelayanan ini, ada sebagian pegawai 
yang bertugas dengan baik tanpa sibuk memperhatikan pekerjaan orang lain namun ada juga sebagian pegawai yang saling bekerjasama dan respon untuk kelancaran pelayanan.

\section{4) Faktor Pendapatan}

Faktor pendapatan meliputi gaji yang dapat menggairahkan semangat kerja yang tinggi. Adapun yang menjadi sub indikator faktor pendapatan adalah gaji yang memuaskan, pemberian uang lembur, pemberian insentif atas kinerja pegawai, pemberian kompensasi tidak langsung, dan pemberian insentif atas semangat kerja pegawai. Untuk mengetahui jawaban responden dari pertanyaan diatas dapat dilihat pada tabel berikut ini :

Tabel 4

Rekapitulasi Tanggapan Responden Indikator Faktor Pendapatan

\begin{tabular}{|c|c|c|c|c|c|c|c|c|c|c|c|}
\hline \multirow{3}{*}{$\begin{array}{l}\text { Indikator } \\
\text { Pelayanan }\end{array}$} & \multicolumn{10}{|c|}{ Persentase \% } & \multirow{3}{*}{ TOTAL } \\
\hline & \multicolumn{2}{|c|}{ SS } & \multicolumn{2}{|c|}{$\mathbf{S}$} & \multicolumn{2}{|c|}{ CS } & \multicolumn{2}{|c|}{ KS } & \multicolumn{2}{|c|}{ TS } & \\
\hline & $\mathbf{F}$ & $\%$ & $\mathbf{F}$ & $\%$ & $\mathbf{F}$ & $\%$ & $\mathbf{F}$ & $\%$ & $\mathbf{F}$ & $\%$ & \\
\hline $\begin{array}{l}\text { Gaji yang } \\
\text { memuaskan }\end{array}$ & 31 & 44 & 18 & 25 & 22 & 31 & - & - & - & - & 71 \\
\hline $\begin{array}{l}\text { Pemberian } \\
\text { uang lembur }\end{array}$ & 22 & 31 & 18 & 25 & 31 & 44 & - & - & - & - & 71 \\
\hline $\begin{array}{l}\text { Pemberian } \\
\text { insentif atas } \\
\text { kinerja } \\
\text { pegawai }\end{array}$ & 13 & 18 & 21 & 30 & 37 & 52 & & - & - & - & 71 \\
\hline $\begin{array}{l}\text { Pemberian } \\
\text { kompensasi } \\
\text { tidak langsung }\end{array}$ & 31 & 44 & 23 & 32 & 17 & 24 & - & - & - & - & 71 \\
\hline $\begin{array}{l}\text { Pemberian } \\
\text { instentif atas } \\
\text { semangat } \\
\text { kerja pegawai }\end{array}$ & 25 & 35 & 37 & 52 & 9 & 13 & - & - & - & - & 71 \\
\hline Jumlah & 122 & & 117 & & 116 & & - & & - & & 355 \\
\hline $\begin{array}{l}\text { Jumlah Rata- } \\
\text { Rata }\end{array}$ & 24,4 & 34 & 23,4 & 33 & 23,2 & 33 & - & - & - & - & $100 \%$ \\
\hline
\end{tabular}

Sumber : Hasil Olahan Data Agustus 2020

Rekapitulasi diatas, memperlihatkan bahwa responden yang menyatakan sangat setuju terdapat 24,4 responden atau sekitar $34 \%$, untuk responden yang menyatakan setuju terdapat 23,4 responden atau $33 \%$ untuk responden yang menyatakan cukup setuju terdapat 23,2 responden atau sekitar $33 \%$.. Hal ini menunjukkan bahwa pendapatan pegawai tidak menjadi kendala atau penghambat untuk mendapatkan pelayanan guna mewujudkan pelayanan yang optimal kepada masyarakat. Responden beranggapan bahwa pendapatan yang mereka terima sudah baik atau sesuai dengan apa yang mereka kerjakan. 


\section{5) Faktor Kemampuan}

Faktor kemampuan dan keterampilan kerja ditingkatkan dengan pemberian bimbingan dan petunjuk-petunjuk kerja, mengadakan pendidikan khusus pegawai. Sub indikator faktor kemampuan adalah cakap dalam penempatan jabatan, kualitas dan potensi pegawai, dinamis dan kreatif, loyal dan berdedikasi tinggi, kemampuan dan kualitas pelayanan. Untuk mengetahui jawaban responden dari pertanyaan diatas dapat dilihat pada tabel berikut ini :

Tabel 5

Rekapitulasi Tanggapan Responden Indikator Faktor Kemampuan

\begin{tabular}{|c|c|c|c|c|c|c|c|c|c|c|c|}
\hline \multirow{3}{*}{$\begin{array}{l}\text { Indikator } \\
\text { Pelayanan }\end{array}$} & \multicolumn{10}{|c|}{ Persentase \% } & \multirow{3}{*}{ TOTAL } \\
\hline & \multicolumn{2}{|c|}{ SS } & \multicolumn{2}{|c|}{$\mathbf{S}$} & \multicolumn{2}{|c|}{$\mathrm{CS}$} & \multicolumn{2}{|c|}{ KS } & \multicolumn{2}{|c|}{ TS } & \\
\hline & $\mathbf{F}$ & $\%$ & $\mathbf{F}$ & $\%$ & $\mathbf{F}$ & $\%$ & $\mathbf{F}$ & $\%$ & $\mathbf{F}$ & $\%$ & \\
\hline $\begin{array}{l}\text { Cakap dalam } \\
\text { penempatan } \\
\text { jabatan }\end{array}$ & 18 & $\begin{array}{l}2 \\
5\end{array}$ & 29 & 41 & 21 & 30 & 3 & 4 & - & - & 71 \\
\hline $\begin{array}{l}\text { Kualitas dan } \\
\text { potensi } \\
\text { pegawai }\end{array}$ & 7 & $\begin{array}{l}1 \\
0\end{array}$ & 16 & 23 & 28 & 39 & 20 & 28 & - & - & 71 \\
\hline $\begin{array}{l}\text { Dinamis dan } \\
\text { kreatif } \\
\text { pegawai }\end{array}$ & 10 & $\begin{array}{l}1 \\
4\end{array}$ & 20 & 28 & 30 & 42 & 4 & 6 & 7 & 10 & 71 \\
\hline $\begin{array}{l}\text { Loyal dan } \\
\text { berdedikasi } \\
\text { tinggi }\end{array}$ & 29 & $\begin{array}{l}4 \\
1\end{array}$ & 21 & 30 & 16 & 23 & 5 & 7 & - & - & 71 \\
\hline $\begin{array}{l}\text { Kemampuan } \\
\text { dan kualitas } \\
\text { pelayanan }\end{array}$ & 24 & $\begin{array}{l}3 \\
4\end{array}$ & 16 & 23 & 26 & 37 & - & - & 5 & 7 & 71 \\
\hline Jumlah & 88 & & 102 & & 121 & & 32 & & 12 & & 355 \\
\hline $\begin{array}{l}\text { Jumlah Rata- } \\
\text { Rata }\end{array}$ & $\begin{array}{l}17, \\
6\end{array}$ & $\begin{array}{l}2 \\
5\end{array}$ & $\begin{array}{l}20 \\
4\end{array}$ & 29 & 24,2 & 34 & 6,4 & 9 & 2,4 & 3 & $100 \%$ \\
\hline
\end{tabular}

Sumber : Hasil Olahan Data Agustus 2020

Rekapitulasi diatas, memperlihatkan bahwa responden yang menyatakan sangat setuju terdapat 17,6 responden atau sekitar $25 \%$, untuk responden yang menyatakan setuju terdapat 20,4 responden atau sekitar $29 \%$, untuk responden yang menyatakan cukup setuju terdapat 24,2 responden atau $34 \%$, untuk yang menyatakan kurang setuju terdapat 6,4 responden atau $9 \%$ dan yang menyatakan tidak setuju sekitar 2,4 atau $3 \%$.

Hal ini menunjukkan bahwa kemampuan pegawai dalam memberikan pelayanan masih belum berhasil. Pernyataan ini diperkuat dengan hasil observasi, dimana tidak semua pegawai yang memiliki pengetahuan yang luas karena dalam pembagian kerja 
pegawai yang bertugas dibagian perizinan dan non perizinan pada penyelesaian Surat Izin Mendirikan Bangunan tidak berdasarkan keahlian masing-masing pegawai dan mayoritas pendidikan pegawai adalah SMA.

Berdasarkan wawancara penulis dengan Informan bernama (Rudi Haurissa, masyarakat yang pernah mengurus IMB) sebagai berikut : "Bagaimana menurut bapak mengenai kemampuan para pegawai dalam memberikan pelayanan di Dinas Penanaman Modal dan Pelayanan Terpadu Satu Pintu Kota Ambon?”.

"Menurut saya, Tidak semua pegawai yang bekerja di Dinas Penanaman Modal dan Pelayanan Terpadu Satu Pintu Kota Ambon berpengalaman. Masih banyak pegawai honorer yang baru bekerja itu kurang mengetahui tentang prosedur IMB. Ketika saya bertanya, mengenai bangunan milik saya akan di perbesar lagi, mereka kebingungan. Justru mereka melempar saya kepada pegawai lainnya."( Wawancara 07 Agustus 2020)

6) Faktor Sarana dan Prasarana

Faktor sarana pelayanan yang meliputi peralatan, perlengkapan dan juga tersedianya fasilitas pelayanan yang meliputi gedung dan segala kegiatannya, fasilitas komunikasi dan fasilitas yang lainnya. Sub indikator faktor sarana dan prasarana adalah sarana kerja yang memadai, kualitas produk, fasilitas ruang unggu, kelengkapan informasi dan bahan-bahan penting, atribut pendukung pelayanan. Untuk mengetahui jawaban responden dari pertanyaan diatas dapat dilihat pada tabel berikut ini :

\section{Tabel 6}

Rekapitulasi Tanggapan Responden Indikator Faktor Sarana dan Prasarana

\begin{tabular}{|c|c|c|c|c|c|c|c|c|c|c|c|}
\hline \multirow{3}{*}{$\begin{array}{l}\text { Indikator } \\
\text { Pelayanan }\end{array}$} & \multicolumn{10}{|c|}{ Persentase \% } & \multirow{3}{*}{ TOTAL } \\
\hline & \multicolumn{2}{|c|}{ SS } & \multicolumn{2}{|c|}{$\mathbf{S}$} & \multicolumn{2}{|c|}{ CS } & \multicolumn{2}{|c|}{$\mathbf{K S}$} & \multicolumn{2}{|c|}{ TS } & \\
\hline & $\mathbf{F}$ & $\%$ & $\mathbf{F}$ & $\%$ & $\mathbf{F}$ & $\%$ & $\mathbf{F}$ & $\%$ & $\mathbf{F}$ & $\%$ & \\
\hline $\begin{array}{l}\text { Sarana kerja } \\
\text { yang } \\
\text { memadai }\end{array}$ & 20 & $\begin{array}{l}2 \\
8\end{array}$ & 10 & 14 & 29 & 41 & 10 & 14 & 2 & 3 & 71 \\
\hline $\begin{array}{l}\text { Kualitas } \\
\text { produk }\end{array}$ & 28 & $\begin{array}{l}3 \\
9\end{array}$ & 20 & 28 & 16 & 23 & 7 & 10 & - & - & 71 \\
\hline $\begin{array}{l}\text { Fasilitas } \\
\text { ruang tunggu }\end{array}$ & 23 & $\begin{array}{l}3 \\
2\end{array}$ & 37 & 52 & 11 & 15 & - & & - & & 71 \\
\hline $\begin{array}{l}\text { Kelengkapan } \\
\text { informasi } \\
\text { dan bahan- } \\
\text { bahanpenting }\end{array}$ & 8 & $\begin{array}{l}1 \\
1\end{array}$ & 17 & 24 & 38 & 54 & 8 & 11 & - & - & 71 \\
\hline $\begin{array}{l}\text { Atribut } \\
\text { pendukung } \\
\text { pelayanan }\end{array}$ & 15 & $\begin{array}{l}2 \\
1\end{array}$ & 20 & 28 & 27 & 38 & 9 & 13 & - & - & 71 \\
\hline Jumlah & 94 & & 104 & & 121 & & 34 & & 2 & & 355 \\
\hline Jumlah Rata- & 19 & 2 & 21 & 29 & 24 & 34 & 7 & 10 & 0,4 & 1 & $100 \%$ \\
\hline
\end{tabular}


Rata 6

Sumber : Hasil Olahan Data Agustus 2020

Rekapitulasi diatas memperlihatkan bahwa responden yang menyatakan sangat setuju terdapat 19 responden atau sekitar $266 \%$, untuk responden yang menyatakan setuju terdapat 21 responden atau sekitar $29 \%$, untuk responden yang menyatakan cukup setuju terdapat 24 responden atau $34 \%$, untuk yang menyatakan kurang setuju terdapat 7 responden atau $10 \%$ dan yang menyatakan tidak setuju sekitar 0,4 atau $1 \%$.

Dari hasil tanggapan responden mengenai pernyataan indikator faktor sarana dan prasarana, mayoritas responden menjawab cukup setuju. Berdasarkan hasil obersvasi, sarana dan prasarana secara khusus belum tersedia, tapi sarana-sarana pokok di Dinas Penanaman Modal dan Pelayanan Terpadu Satu Pintu Kota Ambon sudah disediakan.

Setelah keenam indikator dibahas dan diuraikan diatas, maka untuk mengetahui bagaimana seara keseluruhan faktor-faktor yang menyebabkan keterlambatan pelayanan surat Izin Mendirikan Bangunan Pada Dinas Penanaman Modal dan Pelayanan Terpadu Satu Pintu Kota Ambon berikut ini penulis sajikan rekapitulasi tanggapan responden yang diambil rata-rata jawaban responden setiap kategori dari beberapa indikator yang ada sesuai tabel berikut :

Tabel 7

Rekapitulasi Tanggapan Responden dari Keseluruhan Indikator

\begin{tabular}{|c|c|c|c|c|c|c|c|c|c|c|c|}
\hline \multirow{3}{*}{$\begin{array}{l}\text { Indikator } \\
\text { Pelayanan }\end{array}$} & \multicolumn{10}{|c|}{ Persentase \% } & \multirow{3}{*}{ TOTAL } \\
\hline & \multicolumn{2}{|c|}{ SS } & \multicolumn{2}{|c|}{$\mathbf{S}$} & \multicolumn{2}{|c|}{ CS } & \multicolumn{2}{|c|}{ KS } & \multicolumn{2}{|c|}{ TS } & \\
\hline & $\mathbf{F}$ & $\%$ & $\mathbf{F}$ & $\%$ & $\mathbf{F}$ & $\%$ & $\mathbf{F}$ & $\%$ & $\mathbf{F}$ & $\%$ & \\
\hline $\begin{array}{l}\text { Faktor } \\
\text { Kesadaran }\end{array}$ & 121 & $\begin{array}{l}3 \\
4\end{array}$ & $\begin{array}{l}10 \\
5\end{array}$ & 30 & 129 & 36 & - & - & - & - & 355 \\
\hline $\begin{array}{l}\text { Faktor } \\
\text { Aturan }\end{array}$ & 109 & $\begin{array}{l}3 \\
1\end{array}$ & 81 & 23 & 148 & 42 & 15 & 4 & 2 & 0,1 & 355 \\
\hline $\begin{array}{l}\text { Faktor } \\
\text { Organisasi }\end{array}$ & 105 & $\begin{array}{l}3 \\
0\end{array}$ & $\begin{array}{l}13 \\
3\end{array}$ & $\begin{array}{l}37 \\
4\end{array}$ & 97 & 27 & 15 & 4,2 & 5 & 1,4 & 355 \\
\hline $\begin{array}{l}\text { Faktor } \\
\text { Pendapatan }\end{array}$ & 122 & $\begin{array}{l}3 \\
4\end{array}$ & $\begin{array}{l}11 \\
7\end{array}$ & 33 & 116 & 33 & - & - & - & - & 355 \\
\hline $\begin{array}{l}\text { Faktor } \\
\text { Kemampuan }\end{array}$ & 88 & $\begin{array}{l}2 \\
5\end{array}$ & $\begin{array}{l}10 \\
2\end{array}$ & 29 & 121 & 34 & 32 & 9 & 12 & 3 & 355 \\
\hline $\begin{array}{l}\text { Sarana dan } \\
\text { Prasarana }\end{array}$ & 94 & $\begin{array}{l}2 \\
6\end{array}$ & $\begin{array}{l}10 \\
4\end{array}$ & 29 & 121 & 34 & 34 & 10 & 2 & 1 & 355 \\
\hline Jumlah & 639 & & $\begin{array}{l}64 \\
2\end{array}$ & & 732 & & 96 & & 21 & & 2130 \\
\hline $\begin{array}{l}\text { Jumlah Rata- } \\
\text { Rata }\end{array}$ & $\begin{array}{l}106, \\
5\end{array}$ & $\begin{array}{l}3 \\
0\end{array}$ & $\begin{array}{l}10 \\
7\end{array}$ & 30 & 122 & 34 & 16 & 5 & 3,5 & 1 & $100 \%$ \\
\hline
\end{tabular}


Sumber : Hasil Olahan Data Agustus 2020

Berdasarkan hasil tanggapan responden dari keseluruhan indikator sebagaimana terlihat pada tabel rekapitulasi, bahwa rata-rata persentase responden yang menjawab sangat setuju sebanyak (30\%), responden yang menjawab setuju sebanyak (30\%), responden yang menjawab cukup setuju sebanyak (34\%), responden yang menjawab kurang setuju (5\%) dan yang menjawab tidak setuju sebanyak (1\%).

Dari hasil rekapitulasi diatas dapat diambil kesimpulan Pelayanan Surat Izin Mendirikan Bangunan Pada Dinas Penanaman Modal dan Pelayanan Terpadu Satu Pintu Kota Ambon dari keseluruhan indikator yang telah dianjurkan kepada responden dengan menggunakan teknik pengukuran sesuai dengan pendapat Suharsimi Arikunto sebagai berikut :

a. Sangat Setuju/Sangat Baik : $80-100 \%$

b. Setuju/Baik : 60-79\%

c. Cukup Setuju/Cukup Baik : : 40-59\%

d. Kurang Setuju/Kurang Baik : 30-39\%

e. Tidak Setuju/Tidak Baik : Kurang dari $30 \%$

Dengan menggunakan teknik pengukuran diatas, maka hasil penelitian akan dapat diambil kesimpulan dengan baik yaitu Efektivitas Pelayanan Surat Izin Mendirikan Bangunan di Dinas Penanaman Modal dan Pelayanan Terpadu Satu Pintu Kota Ambon dikategorikan kurang baik karena semua pernyataan positif yang penulis ajukan kepada pegawai sebagai kuesioner, mayoritas pegawai menjawab cukup setuju hal ini sesuai dengan hasil rekapitulasi jawaban responden secara keseluruhan sebesar $34 \%$, artinya pelayanan yang diberikan oleh pegawai kurang baik kepada masyarakat.

Dalam proses pelayanan ditemukan adanya faktor yang menyebabkan keterlambatan atau faktor penghambat penerbitan surat izin mendirikan bangunan di Dinas Penanaman Modal dan Pelayanan Terpadu Satu Pintu Kota Ambon. Namun dari hasil rekapitulasi beberapa faktor yang ada dapat ditarik kesimpulan terdapat 2 (dua) faktor yang paling dominan yaitu :

1. Faktor aturan karena hal ini dapat dilihat pada tabel diatas, ternyata mayoritas responden menjawab cukup setuju dengan pernyataan yang peneliti berikan dalam angket mengenai faktor aturan. Responden beranggapan bahwa aturan yang ada di Dinas Penanaman Modal dan Pelayanan Terpadu Satu Pintu Kota Ambon belum sepenuhnya dijalankan oleh para pegawai diakibatkan kurangnya pengawasan pimpinan

2. Faktor kesadaran, karena hal ini dapat dilihat pada tabel diatas, ternyata mayoritas responden menjawab cukup setuju dengan pernyataan yang peneliti berikan dalam angket mengenai faktor kesadaran. Berdasarkan hasil observasi yang peneliti lakukan pada bulan Juni hingga Agustus 2020, peneliti menilai bahwa kurangnya dsiplin pegawai dalam melaksanakan pelayanan Surat Izin Mendirikan Bangunan sehingga sering terjadi keterlambatan dalam penerbitan surat IMB. 


\section{Kebijakan Yang Dilakukan dalam Peningkatan Pelayanan Surat Izin Mendirikan Bangunan Pada Dinas Penanaman Modal dan Pelayanan Terpadu Satu Pintu Kota Ambon}

Kebijakan-kebijakan yang dilakukan :

1) Berusaha meminimalisir dengan cara mengadakan rapat secara rutin mengenai penerbitan-penerbitan izin yang mengalami keterlambatan. Rapat kepada para pegawai perizinan dan non perizinan tersebut merupakan sosialisasi akan pentingnya kesadaran hukum tentang peraturan Perwa No.53 Tahun 2011 mengenai waktu penyelesaian IMB, selambat-lambatnya terbit adalah 14 hari. Namun kurangnya kesadaran pegawai akan pentingnya Perwali No.53 Tahun 2011.

2) Melakukan pengawasan dan pembinaan yang maksimal kepada pegawai dalam pelayanan dan proses penerbitan izin. Namun keberadaan Kepala Dinas Penanaman Modal dan Pelayanan Terpadu Satu Pintu Kota Ambon yang terkadang dinas di luar kota dan kurangnya pengawasan dari unit-unit yang berwenang menyebabkan pegawai sering melanggar peraturan- peraturan yang ada di Dinas Penanaman Modal dan Pelayanan Terpadu Satu Pintu Kota Ambon.

3) Untuk meningkatkan optimalisasi pelayanan penerbitan surat izin, para pegawai mengikuti pendidikan dan pelatihan-pelatihan bimbingan teknis. Namun, kurangnya ikut serta para pegawai dalam bimbingan teknis dan pelatihan-pelatihan yang ada untuk menambah pengetahuan dan pengalaman mengenai perizinan dan non perizinan.

\section{Kesimpulan}

Berdasarkan hasil penelitian, dalam proses pelayanan ditemukan adanya faktor yang menyebabkan keterlambatan penerbitan surat izin mendirikan bangunan di Dinas Penanaman Modal dan Pelayanan Terpadu Satu Pintu Kota Ambon, sehingga menghambat efektivitas pelayanan Izin Mendirikan Bangunan Namun dari beberapa faktor yang ada dapat ditarik kesimpulan terdapat dua faktor yang paling dominan yaitu:

1. Faktor aturan, hal ini dapat dilihat dari hasil jawaban responden dengan mayoritas menjawab cukup setuju yaitu sebanyak 148 orang atau $42 \%$, dengan pernyataan yang peneliti berikan dalam angket mengenai faktor aturan. Responden beranggapan bahwa aturan yang ada di Dinas Penanaman Modal dan Pelayanan Terpadu Satu Pintu Kota Ambon belum sepenuhnya dijalankan oleh para pegawai diakibatkan kurangnya pengawasan pimpinan.

2. Faktor kesadaran, hal ini dapat dilihat dari hasil jawaban responden dengan mayoritas menjawab cukup setuju yaitu sebanyak 129 orang atau $36 \%$,dengan pernyataan yang peneliti berikan dalam angket mengenai faktor kesadaran. Berdasarkan hasil observasi yang peneliti lakukan pada bulan Juni hingga Agustus 2020, peneliti menilai bahwa kurangnya disiplin dalam pelayanan.

Kebijakan-kebijakan yang dilakukan :

1. Berusaha meminimalisir dengan cara mengadakan rapat secara rutin mengenai penerbitan-penerbitan izin yang mengalami keterlambatan. Rapat kepada para 
pegawai perizinan dan non perizinan tersebut merupakan sosialisasi akan pentingnya kesadaran hukum tentang peraturan Perwa No.53 Tahun 2011 mengenai waktu penyelesaian IMB, selambat-lambatnya terbit adalah 14 hari.Namun kurangnya kesadaran pegawai akan pentingnya Perwa No.53 Tahun 2011.

2. Melakukan pengawasan dan pembinaan yang maksimal kepada pegawai dalam pelayanan dan proses penerbitan izin. Namun keberadaan Kepala Dinas Penanaman Modal dan Pelayanan Terpadu Satu Pintu Kota Ambon yang terkadang dinas di luar kota dan kurangnya pengawasan dari unit-unit yang berwenang menyebabkan pegawai sering melanggar peraturan-peraturan yang ada di Dinas Penanaman Modal dan Pelayanan Terpadu Satu Pintu Kota Ambon.

3. Untuk meningkatkan optimalisasi pelayanan penerbitan surat izin, para pegawai mengikuti pendidikan dan pelatihan-pelatihan bimbingan teknis. Namun, banyak para pegawai yang tidak mengikuti bimbingan teknis dan pelatihan-pelatihan yang ada untuk menambah pengetahuan dan pengalaman mengenai perizinan dan non perizinan. 
Efektivitas Pelayanan Izin Mendirikan Bangunan pada Dinas Penanaman Modal dan Pelayanan Terpadu Satu Pintu Kota Ambon

\section{BIBLIOGRAFI}

Hibali, L. (2012). Kemampuan Aparatur Pemerintah Dalam Pelayanan Izin Mendirikan Bangunan (IMB) di Kota Baru. Google Scholar

Siagian, Sondang P. (2006). Sistem informasi manajemen. Google Scholar

Sugiyono. (2012). Memahami Penelitian Kualitatif. Bandung: CV. Alfabeta. Google Scholar

Sugiyono, P. D. (2017). Metode Penelitian Bisnis: Pendekatan Kuantitatif, Kualitatif, Kombinasi, dan R\&D. Penerbit CV. Alfabeta: Bandung. Google Scholar

Yudhaningsih, Resi. (2011). Peningkatan efektivitas kerja melalui komitmen, perubahan dan budaya organisasi. Jurnal Pengembangan Humaniora, 11(1), 40-50. Google Scholar

\section{Copyright holder:}

Montgomery Warbal (2021)

First publication right:

Syntax Literate: Jurnal Ilmiah Indonesia

This article is licensed under:

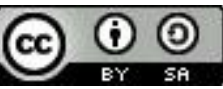

